\title{
Mikroenkapsulasi Asam Mefenamat Menggunakan Polimer Kitosan dan Natrium Alginat dengan Metode Gelasi Ionik
}

\section{(Microencapsulation of Mefenamic Acid Microcapsules With Chitosan and Sodium Alginate as Polymer Using Ionic Gelation Method)}

\author{
Sandra Aulia Mardikasari ${ }^{1 *}$, Suryani ${ }^{2}$, Nur Illiyyin Akib ${ }^{2}$, Rezki Indahyani² \\ $I^{*}$ Fakultas Farmasi, Universitas Hasanuddin, Makassar, Indonesia. \\ ${ }^{2}$ Fakultas Farmasi, Universitas Haluoleo, Kendari, Indonesia. \\ E-mail: sandraaulia@unhas.ac.id
}

Article Info:

Received: 3 Desember 2019

in revised form: 3 Desember 2019

Accepted: 13 Maret 2020

Available Online: 05 Mei 2020

Keywords:

Microencapsulation

Mefenamic Acid

Chitosan

Sodium Alginate

Corresponding Author:

Sandra Aulia Mardikasari

Fakultas Farmasi

Universitas Hasanuddin

Makassar

90245

Indonesia

email: sandraaulia@unhas.ac.id

\begin{abstract}
Mefenamic acid belongs to a class of the Non-steroidal Anti-Inflammatory drugs that work as an analgesic. But mefenamic acid can cause gastrointestinal disorders, has unpleasant odors and tastes and sensitive to the influence of light and temperature. Microencapsulation technology is a technique where the active substance is coated by a thin layer so that the active substance is protected from environmental influences. The aim of this research was to formulate and characterize mefenamic acid in the form of microencapsulation using ionic gelation methods. Preparation was done by comparing 3 variations of concentrations of sodium alginate polymers. Success parameters include the entrapment efficiency, particle shape, particle size distribution, and dissolution test. The results showed that the entrapment efficiency respectively $98,69 \%, 96,38 \%$ and $93,98 \%$, with spherical shape, and particle size that fulfilled the microencapsulation size range of $1,268 \mu \mathrm{m}, 1,343 \mu \mathrm{m}$ and $1.386 \mu \mathrm{m}$ and the release of the active ingredients in an acidic medium of pH 1.2 was $8.811 \mathrm{mg} / \mathrm{L}, 6.751 \mathrm{mg} / \mathrm{L}$ and $5.965 \mathrm{mg} / \mathrm{L}$, also on a base medium of $\mathrm{pH} 7.4$ was $79.908 \mathrm{mg} / \mathrm{L}, 63.394$ $\mathrm{mg} / \mathrm{L}$ and $40,312 \mathrm{mg} / \mathrm{L}$. So that microencapsulation of mefenamic acid can be prepared with polymer chitosan and sodium alginate using the ionic gelation method.
\end{abstract}

c) (1) (5)

Copyright (C) 2019 JFG-UNTAD

This open access article is distributed under a Creative Commons Attribution (CC-BY-NC-SA) 4.0 International license.

How to cite (APA $6^{\text {th }}$ Style):

Mardikasari, S. A., Suryani., Akib, N. I., Indahyani, R. (2020). Mikroenkapsulasi Asam Mefenamat Menggunakan Polimer Kitosan dan Natrium Alginat dengan Metode Gelasi Ionik. Jurnal Farmasi Galenika :Galenika Journal of Pharmacy (eJournal), 6(2), 192-203. doi: 10.22487/j24428744.2020.v6.i2.14589 


\section{ABSTRAK}

Asam mefenamat termasuk dalam golongan obat Anti Inflamasi Non Steroid yang bekerja sebagai analgetik. Tetapi asam mefenamat dapat menyebabkan gangguan pada gastrointestinal, memiliki bau dan rasa yang tidak enak, juga rentan terhadap perngaruh cahaya serta suhu. Teknologi mikroenkapsulasi merupakan teknik dimana zat aktif dilapisi oleh lapisan tipis sehingga zat aktif terlindung dari pengaruh lingkungan. Tujuan dari penelitian ini untuk memformulasi dan mengkarakterisasi asam mefenamat dalam bentuk mikroenkapsulasi menggunakan metode gelasi ionik. Preparasi dilakukan dengan membandingkan 3 variasi konsentrasi dari polimer kitosan dan natrium alginat. Parameter keberhasilan meliputi efisiensi penjerapan, bentuk partikel, distribusi ukuran partikel, serta pengujian disolusi. Hasil yang diperoleh menunjukkan persentase zat aktif yang terjerap berturut-turut sebesar 98,69\%, 96,38\% dan 93,98\%, dengan bentuk partikel yang sferis (bulat), dan ukuran partikel yang memenuhi range ukuran mikroenkapsulasi yaitu $1.268 \mu \mathrm{m}, 1.343 \mu \mathrm{m}$ dan $1.386 \mu \mathrm{m}$ serta pelepasan zat aktif pada medium asam $\mathrm{pH} 1,2$ masing-masing sebesar $8,811 \mathrm{mg} / \mathrm{L}, 6,751 \mathrm{mg} / \mathrm{L}$ dan $5,965 \mathrm{mg} / \mathrm{L}$ juga pada medium basa $\mathrm{pH}$ 7,4 formula sebesar 79,908 mg/L, 63,394 mg/L dan 40,312 mg/L. Sehingga mikroenkapsulasi asam mefenamat dapat dipreparasi menggunakan polimer kitosan dan natrium alginat dengan menggunakan metode gelasi ionik

Kata kunci: Mikroenkapsulasi, Asam Mefenamat, Kitosan, Natrium Alginate.

\section{PENDAHULUAN}

Nyeri merupakan penyakit yang dialami oleh semua kalangan. Setiap individu pasti pernah mengalami nyeri pada tingkatan tertentu (Guyton dan Hall, 2006). Analgetik yang sering digunakan dan diresepkan adalah analgetik golongan non narkotik yang mampu menghilangkan nyeri ringan hingga sedang (Pangalila et al., 2016). Asam mefenamat merupakan analgetik golongan non narkotik secara umum diresepkan untuk mengatasi nyeri akut yang dirasakan setelah efek anestesi mulai berkurang pada pasien (Pangalila, et al., 2016). Namun, perlu diketahui bahwa asam mefenamat dapat menyebabkan iritasi pada mukosa gastrointestinal bila diberikan secara oral untuk jangka waktu lama (Ramanathan, et al., 2010). Selain itu, asam mefenamat juga merupakan obat yang rentan terhadap cahaya dan kelembaban. Perubahan warna, bentuk, ukuran, dapat mempengaruhi khasiat obat dan toksisitas dapat membahayakan pasien. Perubahan warna pada asam mefenamat biasanya disebabkan oleh adanya pemaparan cahaya yang lama pada suhu $30^{\circ} \mathrm{C}$ dan $35^{\circ} \mathrm{C}$. Adanya panas mempercepat terjadinya degradasi asam mefenamat yang ditandai dengan adanya perubahan warna menjadi kuning tua. Waktu paruh yang sempit, iritasi pada mukosa gastrointestinal bila diberikan secara oral untuk jangka waktu lama dan juga ketidakstabilan terhadap suhu, merupakan kekurangan dari asam mefenamat sehingga diperlukan modifikasi terhadap bentuk sediaan asam mefenamat untuk mengatasi kekurangan tersebut (Indrawati, 2010).

Teknologi farmasi saat ini sudah berkembang pesat sehingga dengan adanya perkembangan tersebut industri farmasi akan lebih mudah dalam memproduksi obat-obat dengan kualitas yang baik, khususnya dalam hal kestabilan obat. Stabilitas obat penting untuk diperhatikan karena akan berdampak pada efektifitas, keamanan dan mutu obat (Deviarny, 2012). Salah satu teknologi dalam pembuatan sediaan di indusri farmasi adalah mikroenkapsulasi. Mikroenkapsulasi didefinisikan sebagai partikel bulat dengan ukuran yang bervariasi antara 2-5000 $\mu \mathrm{m}$ yang mengandung zat inti (Jyothi., et al., 2010). Mikroenkapsulasi terus banyak diminati dalam pelepasan terkontrol karena relatif mudah dalam sistem penghantarannya (Singh, 2010). Tidak hanya itu mikroenkapsulasi juga dapat melindungi dan mempertahankan komponen aktif dari pengaruh lingkungan (Purnamayanti, 2016) dan digunakan pula untuk melindungi saluran pencernaan terutama lambung dari iritasi yang disebabkan bahan aktif obat (Rahmadevi, 2013).

Pembuatan mikroenkapsulasi dapat dilakukan dengan menggunakan metode Gelasi Ionik. Gelasi ionik adalah metode yang sederhana dan menghindari pelarut organik berbahaya. Oleh karena itu, metode ini memiliki kemampuan umum untuk melindungi molekul yang dienkapsulasi dan mempertahankan aktivitasnya selama enkapsulasi yang merupakan keuntungan utamanya. Selain itu, ikatan silang fisik reversibel dengan interaksi elektrostatik merupakan ikatan silang kimia yang dapat menghindari 
kemungkinan toksisitas reagen dan efek yang tidak diinginkan lainnya. Beberapa penelitian tentang metode gelasi ionik untuk enkapsulasi makromolekul telah banyak diterapkan. Berbagai polimer alami dan produk turunannya telah berhasil digunakan dalam metode ini untuk berbagai aplikasi farmasi. Dalam metode gelasi ionik, polimer natrium alginat dan kitosan sangat berpotensi membentuk struktur yang sangat terikat silang. Dibandingkan dengan polimer alami lainnya, natrium alginat dan kitosan menghasilkan struktur gel yang lebih seragam yang membentuk struktur ikatan silang yang kuat dan lebih banyak pemuatan bahan yang terperangkap (Ahirrao, et al., 2013).

Dengan adanya penelitian ini diharapkan dapat mengatasi masalah dari asam mefenamat meliputi ketidakstabilan dari paparan cahaya serta melindungi saluran cerna terutama lambung dari iritasi dengan memodifikasinya dalam bentuk mikroenkapsulasi menggunakan polimer kitosan dan natrium alginat dengan metode gelasi ionik. Untuk memastikan mikroenkapsulasi yang terbentuk telah sesuai dengan literatur maka dilakukan karakterisasi mikroenkapsulasi seperti penentuan efisiensi penjerapan, penentuan distribusi ukuran partikel dan bentuk partikel dari mikroenkapsulasi serta pengujian disolusi.

\section{METODE PENELITIAN}

\section{Alat dan Bahan}

Alat-alat yang digunakan dalam penelitian ini adalah Timbangan Analitik (Precisa XB 220A ${ }^{\circledR}$ ), Spektrofotometer UV (Jenway 6800), Stirrer (Model SS30), Oven (Memmert ${ }^{\circledR}$ ), Kertas Saring, pH meter, Pipet Ukur $\left(\right.$ Pyrex $\left.^{\circledR}\right)$, Labu ukur $\left(\right.$ Pyrex $\left.^{\circledR}\right)$, Mikroskop Optik (Nikon SMZ $1500^{\circledR}$ ) serta alat-alat gelas $\left(\right.$ Pyrex $\left.^{\circledR}\right)$.

Bahan-bahan yang digunakan dalam penelitian ini adalah Asam Mefenamat (Hanxin Pharm, China), Kitosan (Brataco), Natrium Alginat (Brataco), Kalsium Klorida (Brataco), Natrium Hidroksida (Brataco), Tween 80 (Brataco), Aquades (Brataco), Asam Asetat (Brataco), Asam Klorida (Brataco), Kalium Klorida (Brataco), Kalium Dihidrogen Fosfat (Brataco), dan Air Bebas $\mathrm{CO}_{2}$.

\section{Metode}

\section{Formulasi Mikroenkapsulasi Asam Mefenamat}

Formula acuan yang digunakan dalam penelitian ini yaitu berdasarkan penelitian yang telah dilakukan oleh Trisnawatii dkk. (2014). Mikroenkapsulasi asam mefenamat dibuat dalam tiga formula yang telah dimodifikasi. Pembuatan mikroenkapsulasi dimulai dengan melarutkan 2 gram asam mefenamat dalam $100 \mathrm{ml} \mathrm{NaOH} 0,1 \mathrm{~N}$, lalu di wadah yang berbeda melarutkan Natrium Alginat dalam aquades dengan konsentrasi $1 \%, 2 \%$ dan 3\% dan Kitosan dalam asam asetat dengan konsentrasi 0,05\%, 0,1\% dan 0,15\%. Selanjutnya larutan asam mefenamat dan larutan alginat yang telah homogen dicampurkan dan diambil menggunakan syringe ukuran $22 \mathrm{G}$ untuk diteteskan ke dalam larutan $\mathrm{CaCl}_{2}$, maka terbentuklah butir mikrokapsul basah. Butiran mikrokapsul dibiarkan terendam dalam $\mathrm{CaCl}_{2}$ selama 10 menit dan selanjutnya disaring menggunakan kertas saring. Setelah disaring, butiran mikrokapsul direndam dalam larutan Tween 80 konsentrasi 3\% selama 10 menit. Lalu butiran disaring dan direndam dalam larutan kitosan selama 10 menit kemudian disaring kembali menggunakan kertas saring dan dikeringkan dalam oven suhu $40^{\circ} \mathrm{C}$ untuk selanjutnya dilakukan karakterisasi.

\section{Karakterisasi Mikroenkapsulasi Asam Mefenamat}

\section{Penetapan Efisiensi Penjerapan Zat Aktif}

Penetapan efisiensi penjeratan zat aktif dilakukan dengan cara menimbang mikrokapsul $100 \mathrm{mg}$ dan dilarutkan dalam $100 \mathrm{~mL}$ dapar fosfat $\mathrm{pH}$ 7,4 diaduk tanpa memecah mikrokapsul. Kemudian diambil $1 \mathrm{~mL}$ dan diencerkan hingga $25 \mathrm{~mL}$ lalu diambil lagi $2 \mathrm{~mL}$ dan diencerkan hingga $10 \mathrm{~mL}$ dapar fosfat. Kemudian diukur serapannya pada panjang gelombang maksimum yang telah diperoleh menggunakan 
spektrofotometri UV-Vis. Serapan yang diperoleh, dimasukkan ke dalam persamaan kurva kalibrasi untuk mendapatkan konsentrasi asam mefenamat yang terjerap. Efisiensi dihitung dengan rumus :

$$
\mathrm{EE}=\frac{T-D}{T} \times 100 \%
$$

Ket $: \mathrm{T}=$ Total jumlah obat yang ditambahkan dalam formula $; \mathrm{D}=$ Jumlah obat yang larut (Srifiana, dkk 2014).

\section{Distribusi Ukuran Partikel}

Pengukuran partikel dilakukan dengan menggunakan mikroskop optik. Mikrokapsul yang akan diamati diletakkan dicawan petri dan selanjutnya dicari partikel yang diinginkan untuk memulai pengukuran diameter partikel (300 partikel) menggunakan program pengukuran diameter patrikel atau sejenisnya. Kemudian ditentukan keseluruhan diameter rata-rata dan dibuat kurva distribusi ukuran partikel (Utama, et al., 2013).

\section{Pengamatan Bentuk Partikel}

Mikrokaenkapsulasi diletakkan pada objek glass dan ditetesi dengan paraffin cair kemudian ditutup dengan cover glass dan diletakkan dibawah mikroskop. Atur sedemikian rupa sehingga didapat bentuk yang jelas (Noviza, et al., 2013).

\section{Pengujian Disolusi}

Uji disolusi menggunakan larutan dapar fosfat $\mathrm{pH}$ 7,4 dan larutan dapar asam klorida $\mathrm{pH}$ 1,2 sebagai medium disolusinya sebanyak $900 \mathrm{~mL}$. Metode yang digunakan yaitu metode dayung. Langkah kerjanya, yaitu langkah pertama pembuatan dapar fosfat $\mathrm{pH}$ 7,4 sebanyak 1 liter dengan mencampurkan $250 \mathrm{~mL}$ kalium dihidrogen fosfat 0,2 $\mathrm{M}$ ditambahkan 39,1 mL NaOH 0,2 $\mathrm{N}$ kemudian diencerkan dengan air bebas $\mathrm{CO}_{2}$ hingga 1 liter. Langkah kedua masukan $900 \mathrm{~mL}$ larutan dapar fosfat $\mathrm{pH} 7,4 \mathrm{ke}$ dalam labu disolusi. Langkah ketiga pasang alat disolusi, biarkan media disolusi hingga suhu $37^{\circ} \pm 0,5^{\circ}$ dengan pemanasan pada penangas air bertermostat. Langkah keempat masukan mikrokapsul ke dalam alat disolusi, alat dijalankan dengan laju kecepatan $50 \mathrm{rpm}$. Langkah kelima dilakukan pengambilan sampel $10 \mathrm{~mL}$, dilakukan pada jam ke-1, 2, 3 4, 6, dan 8. Posisi pengambilan sampel pada daerah pertengahan antara permukaan media disolusi dan bagian atas dari daun alat tidak kurang $1 \mathrm{~cm}$ dari dinding wadah. Setiap larutan percobaan yang diambil diganti kembali sehingga medium tetap berjumlah $900 \mathrm{~mL}$. Larutan $10 \mathrm{~mL}$ yang diambil diukur serapannya pada panjang gelombang maksimum dengan Spektrovotometer UV-Vis dan uji yang sama dilakukan dengan menggunakan buffer asam klorida $\mathrm{pH} 1,2$, perlakuan yang sama dilakukan pada masing-masing formula dan hitung kadar zat aktif yang terdisolusi (Kurniawan, 2015).

\section{HASIL DAN PEMBAHASAN}

\section{Formulasi Mikroenkapsulasi Asam Mefenamat}

Mikroenkapsulasi merupakan proses penggunaan penyalut yang relatif tipis pada partikel-partikel kecil zat padat atau tetesan cairan dan dispersi zat cair, dimana ukuran partikel berkisar antara 2-5000 $\mu \mathrm{m}$. Proses mikroenkapsulai akan menghasilkan bentuk sediaan yang disebut mikrokapsul. Mikrokapsul didefinisikan sebagai suatu partikel yang mengandung zat aktif atau material inti yang dikelilingi oleh pelapis atau cangkang. Dengan adanya lapisan dinding polimer ini, zat inti akan terlindungi dari pengaruh lingkungan luar. Bahan inti dapat berupa padatan, cairan, atau gas sedangkan penyalut terbuat dari polimer organik, lemak, dan lilin. Teknik mikroenkapsulasi biasa digunakan untuk meningkatkan stabilitas, mengurangi efek samping dan efek toksik obat, serta memperpanjang pelepasan obat (Benita., 2006). Salah satu penelitian yang dilakukan oleh Hasrini (2017) menemukann bahwa teknik mikroenkapsulasi dapat digunakan untuk meningkatkan stabilitas dari minyak sawit mentah. Selain itu 
penelitian dari Kamala (2010) teknik mikroenkapsulasi dapat digunakan untuk mengubah vitamin A menjadi serbuk sehingga dapat melindungi senyawa inti dari pengaruh luar. Penelitian yang dilakukan oleh Kurniawan (2015) teknik mikroenkapsulasi dapat memperpanjang pelepasan obat dari Lansoprazol.

Pada prinsipnya mikrokapsul terdiri atas tiga bahan utama yaitu bahan inti, bahan penyalut dan pelarut. Bahan inti adalah bahan spesifik yang akan dilapisi, dapat berupa bahan padat, cair atau gas. Bahan inti yang digunakan sebaiknya tidak alrut atau tidak bereaksi dengan bahan penyalut dan pelarut yang digunakan. Bahan penyalut adalah bahan yang digunakan untuk menyelaput inti dengan tujuan tertentu seperti menutupi bau dan rasa yang tidak enak, perlindungan terhadap lingkungan, stabilitas, dan pencegahan penguapan. Bahan penyalut harus mampu memberikan suatu lapisan tipis yang kohesif dengan bahan inti, dapat bercampur secara kimia, tidak bereaksi dengan inti (bersifat inert) dan mempunyai sifat yang sesuai dengan tujuan penyalutan. Terdapat beberapa jenis bahan penyalut. Penyalut atau polimer seperti alginat-kitosan merupakan polimer yang sangat baik dalam membantu kinerja mikroenkapsulasi. Natrium alginat dan kitosan menghasilkan struktur gel yang lebih seragam yang membentuk struktur ikatan silang yang kuat dan lebih banyak pemuatan bahan yang terperangkap (Ahirrao, et al., 2013). Selain itu, polimer anionik seperti alginat dan polimer kationik seperti kitosan berada bersama dalam larutan, terbentuk kompleks polielektrolit. Kompleks polielektrolit merupakan kompleks asosiasi yang terbentuk antara poliion dengan muatan yang berlawanan karena adanya interaksi elektrostatik anatara poliion dengan bermuatan tersebut (Lankalapalli, 2009). Dalam hal ini, muatan negatif gugus asam karboksilat dari alginat akan berikatan dengan muatan positif gugus amino dari kitosan secara ionik (Liouni, et al., 2008).

Proses mikroenkapsulasi dapat dilakukan dengan berbagai macam metode, salah satunya yaitu metode gelasi ionik. Penggunaan metode gelasi ionik hal terpenting yang dibutuhkan dalam pembentuk mikroenkapsulasi yaitu pengikat silang yang berfungsi sebagai pengeras dan mempertahankan bentuk mikropartikel. Agen sambung silang yang telah banyak digunakan yaitu kalsium klorida $\left(\mathrm{CaCl}_{2}\right)$, dimana agen sambung silang ini dapat mengontrol pelepasan bahan aktif dari bentuk sediaan oral dengan silang alginat atau dengan kitosan (Firdyawati, 2014). Prosedur pembuatan mikrokapsul alginat-kitosan dapat dilakukan dengan dua tahap yaitu pertama menteskan larutan natrium alginat kedalam larutan yang mengandung ion kalsium seperti $\mathrm{CaCl}_{2}$, kemudian tahap kedua memindahkan mikrokapsul tersebut ke dalam larutan kitosan untuk membentuk membran pada permukaan mikrokapsul alginat (Gaserod, et al., 1998).

Pembuatan mikroenkapsulasi asam mefenamat pada penelitian ini menggunakan variasi konsentrasi polimer yang berbeda dengan tujuan untuk melihat pengaruh dari konsentrasi polimer yang digunakan terhadap karakteristik fisik mikroenkapsulasi yang terbentuk. Sesuai dengan modifikasi formula yang diperoleh maka dilakukan pembuatan formula mikroenkapsulasi asam mefenamat. Hasil pembuatan ketiga formula mikroenkapsulasi asam mefenamat dapat dilihat pada Gambar 1.
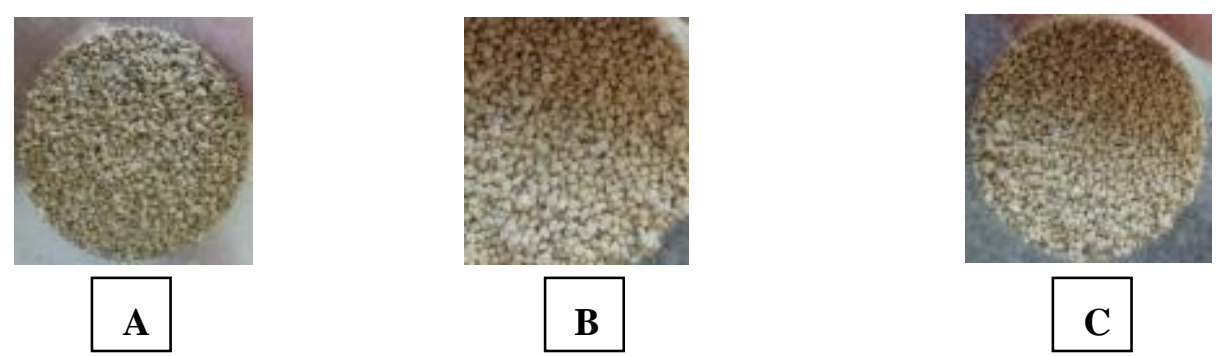

Gambar 1. Mikroenkapsulasi Asam Mefenamat (A) Formula I, (B) Formula II, (C) Formula III

Dari hasil yang didapatkan, terlihat bahwa mikroenkapsulasi asam mefenamat berbentuk butiran bulat kecil. Terbentuknya butiran ini disebabkan saat natrium alginat diteteskan pada larutan $\mathrm{CaCl}_{2}$. Larutan $\mathrm{CaCl}_{2}$ berfungsi sebagai agen pengikat silang dan juga untuk repolimerisasi asam guluronat dan asam 
manuronat yang terdapat pada alginat. Alginat yang semula berupa garam Na-alginat dengan ion $\mathrm{Na}$ sebagai pengikat silang antara gugus asam manuronat dan asam guluronat ini terputus saat alginat dilarutkan dalam akuades. Pada saat penetesan ke dalam larutan $\mathrm{CaCl}_{2}$, polimer tersebut dapat berikatan lagi, yaitu ditandai dengan terbentuknya butiran yang masih berbentuk gel (Trisnawati, 2014).

\section{Penetapan Efesiensi Penjerapan}

Efisiensi penjerapan dilakukan untuk mengetahui kemampuan polimer dalam menjerap zat aktif dan mengetahui efisiensi dari metode yang digunakan. Hasil penetapan efesiensi penjerapan mikroenkapsulasi yang telah dilakukan dapat dilihat pada grafik yang ditampilkan pada Gambar 2.

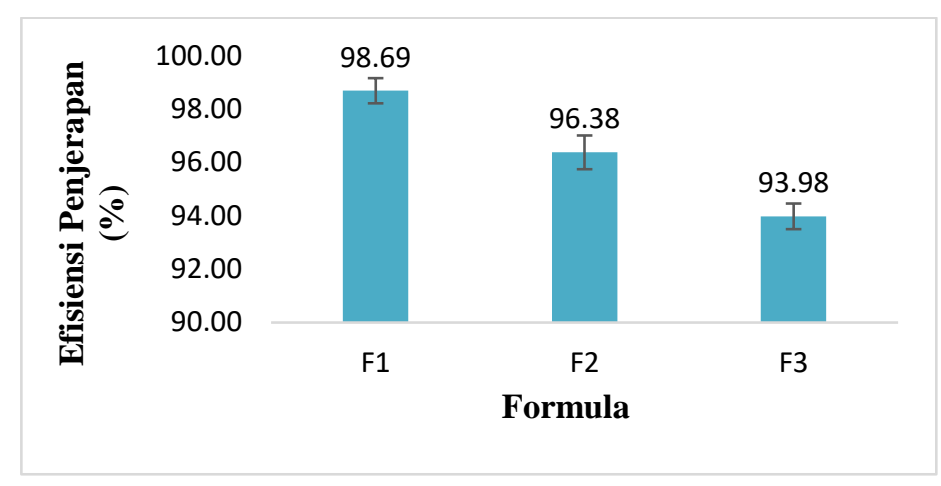

Gambar 2. Nilai Efisiensi Penjerapan Mikroenkapsulasi

Hasil dari grafik diatas menunjukkan nilai efisiensi penjerapan terbesar yaitu pada F1, kemudian F2 dan terkecil pada F3. Dimana dari hasil tersebut menunjukkan bahwa peningkatam konsentrasi penyalut alginat-kitosan akan menurunkan efisiensi enkapsulasi asam mefenamat. Hal ini disebabkan karena peningkatan konsentrasi penyalut alginat-kitosan dapat menghasilkan pori-pori gel yang terbentuk semakin rapat sehingga permeabilitas terhadap obat semakin kecil dan tidak terjerap dalam inti (Ratna, 2013). Selain itu, peningkatan konsentrasi alginat menyebabkan semakin banyak ikatan antara gugus karboksilat dari alginat dengan ion $\mathrm{Ca}^{2+}$. Semakin banyaknya ikatan maka struktur ikatan akan semakin rumit yang mengakibatkan semakin kecil pori yang terbentuk sehingga terjadinya penurunan porositas (Gayo, 2016).

Penentuan efesiensi penjerapan mikrokapsul biasanya tidak mencapai 100\% dikarenakan adanya zat aktif ikut terbawa pada proses pencucian dan juga adanya zat aktif yang menempel pada dinding mikroenkapsulasi (Azhar, et al.,2010). Pada pengujian ini zat aktif yang diukur hanya pada bagian luar mikroenkapsulasi saja, karena jika mengukur aquades bekas pencucian mikroenkapsulasi kemungkinan besar bukan hanya zat aktif yang ada dalam aquades tersebut, karena tujuan utama pencucian untuk menghilangkan $\mathrm{Cl}^{-}$yang tidak terikat pada proses sambung silang, selain itu asam mefenamat juga tidak larut air sehingga tidak memungkinkan mengukur asam mefenamat dalam medium air.

\section{Distribusi Ukuran Partikel Mikrokapsula Asam Mefenamat}

Distribusi ukuran partikel merupakan evaluasi fisik pada mikroenkapsulasi untuk mengetahui diameter rata-rata pada partikel (Hinrics et al., 2006). Metode yang digunakan yaitu dengan mikroskop optik. Hasil distribusi yang diperoleh setelah melakukan pengukuran partikel mikroenkapsulasi dapat dilihat pada grafik yang ditampilkan pada Gambar 3 . 


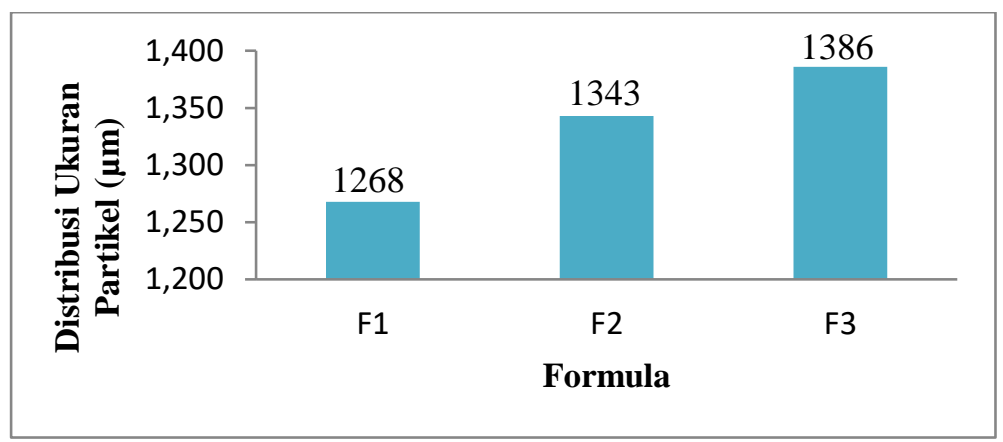

Gambar 3. Grafik distribusi ukuran partikel mikrokapsul

Grafik distribusi ukuran partikel menunjukkan bahwa semakin tinggi perbandingan polimer yang digunakan, semakin besar pula ukuran partikel yang dihasilkan (Rosida, 2010). Ukuran mikroenkapsulasi yang beragam dipengaruhi oleh beberapa faktor, diantaranya konsentrasi polimer, jarak antara jarum suntik dan larutan pembentuk mikrokapsul, perbedaan tekanan saat pembentukan mikrokapsul melalui syringe, tinggi rendahnya posisi syringe saat menjatuhkan mikroekapsul ke dalam $\mathrm{CaCl}_{2}$, maupun ukuran diameter syringe yang digunakan dalam proses pembuatan. Bentuk mikrokapsul dapat terbentuk homogen jika digunakan alat peristaltic pump sehinggaa memudahkan dalam pengerjaan proses enkapsulasi dengan metode gelasi ionik (Sari, 2010). Hasil pengukuran mikrokapsul yang diperoleh membuktikan bahwa ketiga formula yang dibuat telah mencapai target yang diharapkan, mikrokapsul yang terbentuk masuk rentang mikrokapsul dengran menggunakan metode gelasi ionik

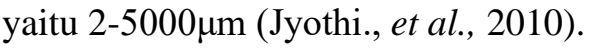

\section{Bentuk Partikel Mikrokapsul}

Pengamatan sifat mikroskopis mikrokapsul asam mefenamat dilakukan dengan menggunakan mikroskop. Hasil yang diperoleh menunjukan bahwa mikrokapsul yang dihasilkan berbentuk sferis dengan ukuran yang berbeda tiap formula pada pembesaran 10 kali. Semakin banyak jumlah polimer yang digunakan maka semakin tebal penyalut yang menyelubungi zat aktif sehingga mikrokapsul yang dihasilkan semakin besar (Lachman, et al., 1989). Hasil pengamatan mikroskopis dapat dilihat pada Gambar 4.

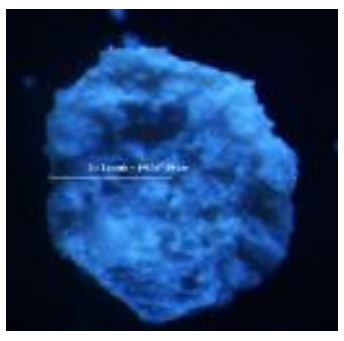

\section{A}

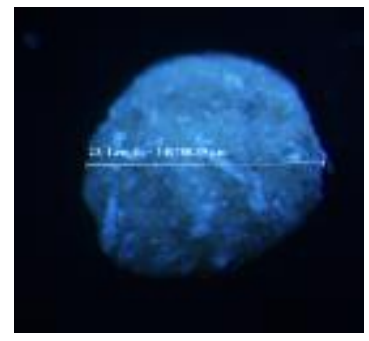

B

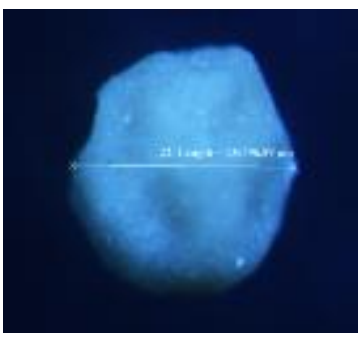

C

Gambar 4. Pengamatan bentuk partikel mikroenkapsulasi (A) Formula I, (b) Formula II, (C) Formula III

Dari gambar diatas dapat dilihat jika formula 1 sampai formula 3 memiliki bentuk spheris, hal ini menunjukkan bahwa asam mefenamat yang dibuat dalam bentuk mikroenkapsulasi dengan metode gelasi ionik memenuhi karakterisasi bentuk partikel, dimana bentuk mikroenkapsul yang diinginkan yakni spheris (Sari, 2010).

Hasil mikrokapsul yang spheris menunjukkan bahwa obat telah tersalut dengan baik sehingga membuat obat menjadi lambat pelepasannya, berbeda dengan bentuk yang tidak spheris menandakan adanya rongga-rongga yang terbentuk sehingga mengakibatkan obat keluar dengan cepat. Dalam sistem 
penghantaran obat yang menggunakan partikel sebagai penghantar seperti mikropartikel, kemampuan menyalut obat yang tinggi dengan ukuran partikel yang kecil dan bentuk spheris yang seragam adalah lebih baik. Hal ini akan memudahkan pemberian obat melalui rute tertentu seperti pemberian secara intravena, intranasal, dan sebagainya (Herdini, et al., 2010).

\section{Disolusi Mikrokapsul Asam Mefenamat}

Pengujian laju disolusi dilakukan untuk melihat kecepatan melarutnya zat kimia atau senyawa obat dari sediaan padat ke dalam suatu medium tertentu. Pengujian ini juga diperlukan untuk menunjukkan apakah mikroenkapsulasi yang dibuat berhasil mempunyai sistem penghantaran yang baik disaluran gastrointestinal. Adapun hasil pelepasan mikroenkapsulasi asam mefenamat dapat dilihat pada gambar kurva pelepasan berikut.

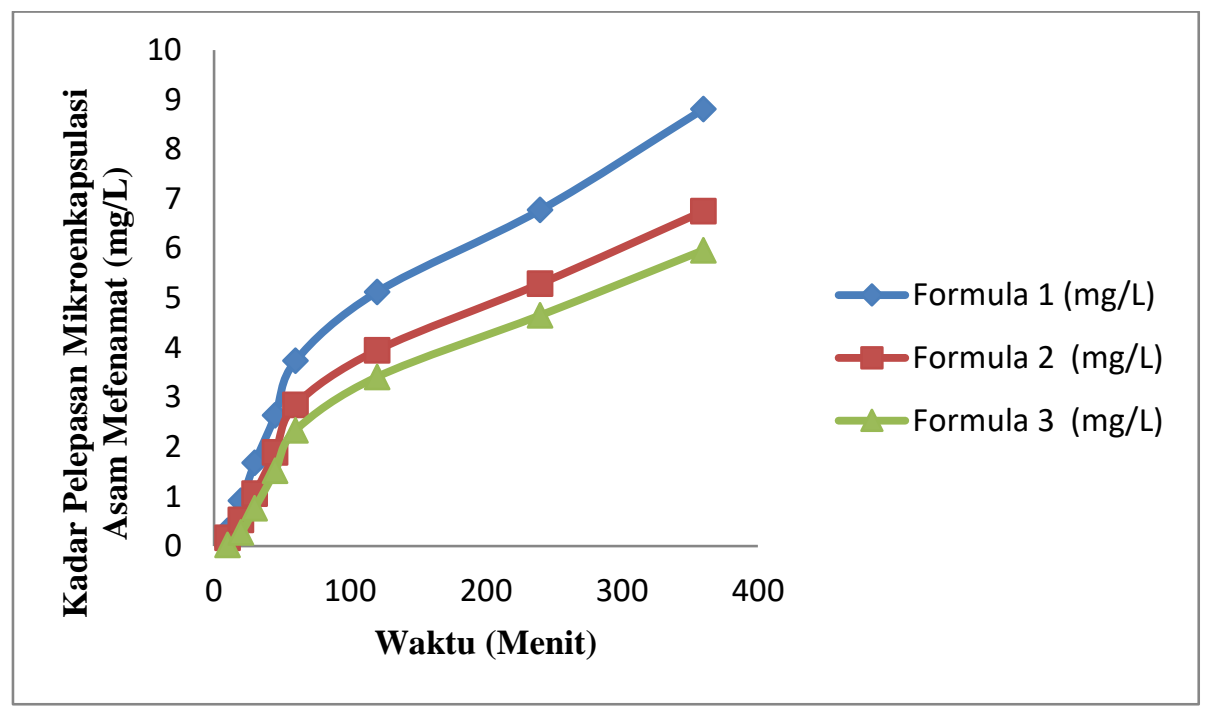

Gambar 5. Hasil disolusi mikroenkapsulasi asam mefenamat pada $\mathrm{pH}$ 1,2

Kurva diatas menampilkan profil kadar pelepasan mikroenkapsulasi asam mefenamat pada $\mathrm{pH} 1,2$ dimana pada kurva tersebut terlihat pelepasan yang terjadi secara perlahan-lahan. Dari kurva juga dapat menjelaskan pelepasan mikroenkapsulasi pada tiap formula berbeda. Disini terlihat bahwa perbandingan polimer dari tiap formula membuktikan semakin banyak konsentrasi polimer, maka pelepasan obat akan semakin lambat (Bolourtchian, 2005), terbukti pada F1 yang memiliki perbandingan konsentrasi polimer yang paling sedikit, sehingga membuat pelepasannya lebih cepat dibanding F2 dan F3 dengan perbandingan konsentrasi polimer yang lebih banyak.

Pelepasan mikroenkapsulasi asam mefenamat di $\mathrm{pH}$ 1,2 pada F1 mampu melepaskan zat aktif sebanyak 8,811 mg/L dimenit ke-360, pada F2 sebanyak 6,751mg/L sedangkan pada F3 sebanyak 5,965 mg/L. Hal ini terjadi karena kitosan yang berpotensi larut pada medium asam sehingga membuat polimer dapat melepaskan obat didalamnya, namun dengan bantuan alginat, pelepasan obat yang terjadi tidak begitu besar karena sifat alginat pada pH 1,2 menjadi asam alginat yang bersifat hidrofob sehingga menjadi sukar larut (Sari, 2016). 


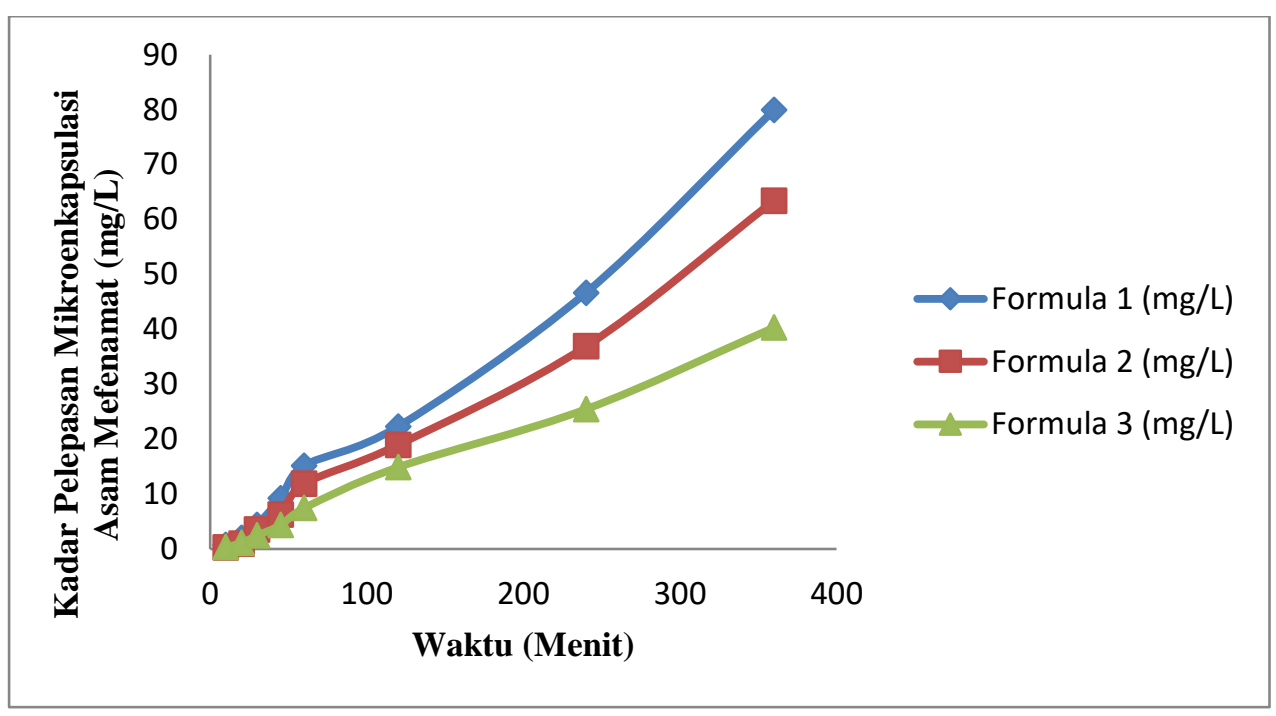

Gambar 6. Hasil Disolusi Mikroenkapsulasi Asam Mefenamat pada pH 7,4

Sedangkan di pH 7,4 kurva pelepasan mikroenkapsulasi asam mefenamat menunjukkan pada F1 mampu melepaskan zat aktif sebesar 79,908 mg/L dimenit ke-360 dan pada F2 mampu melepaskan zat aktif sebesar 63,394 mg/L sedangkan pada F3 sebesar 40,312 mg/L. Hal ini terjadi karena sifat alginat yang mudah larut pada $\mathrm{pH}$ basa sehingga membuat obat mudah keluar dari polimer, namun dengan adanya kitosan yang mampu bertahan didaerah basa sehingga pelepasan obat yang terjadi menjadi lebih lambat (Firdyawati, 2014).

Pelepasan asam mefenamat dari polimer kitosan-alginat dimulai ketika polimer kontak langsung dengan medium disolusi, terjadi penetrasi cairan kedalam polimer, sehingga polimer akan mengembang dan membentuk gel. Lapisan gel berfungsi sebagai penghalang disekeliling polimer yang mengontrol pelepasan obat dari dalam polimer. Semakin tebal lapisan gel yang menghalangi semakin sulit obat berdifusi keluar polimer. Oleh karena itu waktu yang dibutuhkan untuk melepaskan sejumlah obat menjadi lebih lama. Obat yang berada pada lapisan terdekat dengan polimer yang akan pertama kali berdifusi (Herdini, et al., 2010).

Keberadaan bahan enkapsulasi seperti kitosan-alginat memperkuat jejaring polimer mikrokapsul sehingga pelepasan asam mefenamat dalam asam menjadi terkendali dan waktu paruhnya menjadi lebih panjang, diharapkan dapat menurunkan frekuensi pemberian obat terhadap penderita dan dapat menurunkan efek sampingnya (Abror, 2015). Kedua kurva pelepasan diatas menggambarkan bahwa pelepasan obat pada medium asam $\mathrm{pH}$ 1,2 yang terjadi begitu kecil. Hal ini disebabkan oleh besarnya konsentrasi natrium alginat yang digunakan. Sedangakn pada medium basa $\mathrm{pH}$ 7,4 pelepasan obat yang terjadi begitu besar, dimana hal ini disebabkan oleh rendahnya konsentrasi kitosan yang digunakan karena diharapkan asam mefenamat dapat terlepas diusus dengan kadar yang besar.

Selain itu, kecepatan disolusi juga dipengaruhi oleh bentuk partikel yang dihasilkan. Seperti yang diketahui pada pengujian distribusi ukuran partikel FI menghasilkan ukuran yang lebih kecil dibandingkan dengan FII dan FIII. Sehingga luas permukaan untuk berinteraksi dengan medium lebih luas dan mempercepat proses disolusi (Kasih, 2014). Dosis yang biasa diberikan asam mefenamat adalah 200-500 mg diberikan tiga kali sehari. Asam mefenamat cepat diserap setelah pemberian oral. Kadar plasma asam mefenamat adalah 20mg/L (Uddin, et al., 2014). Setelah melihat pelepasan mikrokapsul asam mefenamat pada medium basa, maka dapat dikatakan bahwa pelepasan asam mefenamat memenuhi rentang untuk menimbulkan efek ketika berada disaluran cerna yaitu usus. 


\section{KESIMPULAN}

Mikroenkapsulasi asam mefenamat dapat diformulasi menggunakan polimer kitosan dan natrium alginat melalui metode gelasi ionik dengan perolehan nilai efesiensi penjerapan yakni $98,69 \%$, distribusi ukuran partikel sekitar $1.268 \mu \mathrm{m}$, dan memiliki bentuk partikel yang sferis. Untuk hasil disolusi menunjukkan bahwa semakin banyak jumlah polimer kitosan dan natrium alginat yang digunakan maka akan semakin memperlambat waktu pelepasan obat.Pernyataan yang singkat sebagai bentuk kesimpulan/dan saran untuk penelitian berikutnya pada bagian akhir dari bab ini.

\section{DAFTAR PUSTAKA}

Abror, M. U. S., \& Sari, E. C. (2015). Pengaruh Konsentrasi Agen Pengikat Silang Terhadap Karakteristik Pirasinamid Terenkapsulasi. UNESA Journal of Chemistry, 4(1).

Ahirrao, S. P., Parage S. G., Shrivastav, B., \& Pankaj, S. (2013). Iontropic Gelation : A promising Cross Linking Techinque for Hydrogels. Research and Reviews : Journal of Pharmaceutics and Nanotechnology, 1(1).

Azhar, Rieke, Elva \& Auzal. (2010). Mikroenkapsulasi Paracetamol dengan HPMC Menggunakan Metode Penguapan Pelarut. Jurnal Farmasi, 2(2).

Benita, S. (2006). Microencapsulation: Methods and Industrial Application Edisi 2. Boca Raton: CRC Press.

Bolourtchian, N., Karimi, K., \& Aboofazeli, R. (2005). Preparation and Characterization Ibuprofen Microsphere. Journal on Microencapsulation.

Deviarny, C., Henny, L., \& Safni. (2012). Uji Stabilitas Kimia Natrium Askorbil Fosfat dalam Mikroemulsi dan Analisisnya dengan HPLC. Jurnal Farmasi Andalas Padang, 1(1).

Firdyawati, S. (2014). Formulasi Mikropartikel Teofilin Menggunakan Penyalut Kitosan-Alginat yang Dipaut Silang dengan Natrium Tripolifosfat. (Unpublished Undergraduate Thesis). Universitas Hasanuddin, Makassar.

Gayo, C. D. (2016). Pengaruh Variasi Konsentrasi Natrium Alginat Terhadap Efisiensi Penjerapan Mikrokapsul Minyak Biji Jinten Hitam (Nigella sativa L.). (Unpublished Undergraduate Thesis). Universitas Islam Negeri Syarif Hidayatullah, Jakarta.

Gaserod, O. \& Smidsrod, G. S. (1998). Microcapsules of alginate - chitosan - I A Quantitative study of the interaction between alginate and chitosan. Biomaterials 19.

Guyton \& Hall JE. (2006). Buku Ajar Fisiologi Kedokteran. Edisi 11. Penterjemah: Irawati, Ramadani D, Indriyani F. Jakarta: Penerbit Buku Kedokteran EGC.

Hasrini, R., Zakaria, F., Adawiyah, D., \& Suparto, I. (2017). Mikroenkapsulasi Minyak Sawit Mentah dengan Penyalut Maltodekstrin dan Isolat Protein Kedelai. J. Teknol dan Industri pangan, 28(1).

Herdini, Latifah, K. D., \& Purwantiningsih, S. (2010). Disolusi Mikroenkapsulasi Kurkumin Tersalut Gel Kitosan-Alginat-Glutaraldehida. Makara Sains, 14(1).

Hinrichs, W. L. J. (2006). The Choice of a Suitable Oligosaacharide to Prevent Aggregation of PEGylated Nanoparticles during Freeze Thawing and Freeze Drying. International Journal of Pharmaceutics.

Indrawati, T., \& Sari, N.K. (2010). Stabilitas Kaplet Asam Mefenamat Dengan. Suhu dan Kelembaban Ruang Penyimpanan yang Berbeda. Makara Kesehatan, 14(2). 
Jyothi, N.V.N., Muthu. P. P., Suhas, N. S., Surya, K. P., Seetha, P. R., \& Srawan, G., Y. (2010). Microencapsulation Techniques, Factor Influenching Encapsulation Efficiecy. Journal of Microencapsulation, 27(3).

Kasih, R., Avadi, M., \& Khaksar, R. (2014). Formulation Optimization of Nifedipin Containing Microspheres Using Factorial Design. African Journal of Pharmacy and Pharmacology, 4(6), 346-354.

Kurniawan, R., \& Deni R. (2015). Mikroenkapsulasi Controlled Release Lansoprazol dengan Kombinasi Hydroxy Propyl Methyl Cellulose Phthalate dan Natrium Alginat secara Gelasi Ionotropik. Jurnal Ilmu Kefarmasian Indonesia, 14(1).

Kumala, N. (2010). Mikroenkapsulasi Vitamin A Palmitat dengan menggunakan Gelatin-Akasia secara Koaservasi Kompleks. (Unpublished Undergraduate Thesis). Universitas Indonesia, Jakarta.

Lachman, L., Liberman, H.A., \& Kaning, J. L. (1994). Teori dan Praktek farmasi Industri. Jakarta: Universitas Indonesia Press.

Lankalapalli S., \& Kolapalli V. (2009). Polyelectrolyte complexes: a review of their applicability in drug delivery technology. Ind. J Pharm Sci, 71(5).

Liouni, M., Drichoutis, P., \& Nerantis, E.T. (2008). Studies of the Mechanical Properties and the Fermentation Behavior of Double Layer Alginat-Chitosan Beds, Using Saccharomyces cerevisiae Entrapped Cells. Word J Microbiol Biotechnol, 24.

Noviza, D., Tita H., \& Ade, A.R. (2013). Mikroenkapsulasi Metformin Hidroklorida dengan Penyalut Etilselulosa Menggunakan Metoda Penguapan Pelarut. Jurnal Sains dan Teknologi Farmasi, 18 (1).

Pangalila, K., Pemsi, W. M., \& Bernat, S.P.H., (2016). Perbandingan Efektivitas Pemberian Asam Mefenamat dan Natrium Diklofenak Sebelum Pencabutan Gigi Terhadap Durasi Ambang Nyeri Setelah Pencabutan Gigi. Jurnal e-GiGi (eG), 4(2).

Purnamayanti, L., Dewi, E., N., \& Kurniasih, R., A. (2016). Karakteristik Fisik Mikrokapsul Fikosianin Spirulina Pada Konsentrasi Bahan Penalut Yang Berbeda. Jurnal Teknologi Hasil Pertanian, 9(1).

Rahmadevi, Erizal, Z., \& Auzal, H. (2013). Penggunaan Eudragit L 100 dalam Formulasi Mikrokapsul Natrium Diklofenak dengam Teknik Emulsifikasi-Penguapan Pelarut. Jurnal Andalas, 1(1).

Ramanathan, G., Kavitha, K., Archana, T.N., Naili, C.N., \& Anandkumar, M. A. (2010). Formulation Of Floating Tablets Of Mefenamic Acid With Different Grades Of Hydroxy Propyl Methyl Cellulose Polymer and Studying The Release Profiles. International Journal of Drug Development \& Research, 2(3).

Ratna, A. (2013). Sintesis dan Karakterisasi Membran Kitosan-PEG (Polietilen Glikol) sebagai Alternatif Pengontrol Sistem Pelepasan Obat. (Unpublished Undergraduate Thesis). Universitas Negeri Semarang, Semarang.

Rosida, I. (2010). Mikroenkapsulasi Fraksi Aktif dari herba Sambiloto (Andrographis paniculata Ness) yang Berkhasiat Sitotoksik dengan Metode Semprot Kering. (Unpublished Undergraduate Thesis). Universitas Indonesia, Jakarta.

Sari, D. P., \& Marline, A., (2016). Review Article: Efek Kitosan Terhadap Kontrol Pelepasan Obat. Farmaka, 15(2). 
Singh, M. N., Hernant, M., Ram, \& Shivakumar, H. G. (2010). Microencapsulation: A Promising Technique for Controlled Drug Delivery. Journal Research in Pharmaceutical Science.

Srifiana, Y., Silvia, S., \& Arry, Y. (2014). Mikroenkapsulasi Ketoprofen dengan Metode Koaservasi dan Semprot Kering Menggunakan Pregelatinisasi Pati Singkong Ftalatnsebagai Eksipien Penyalut. Jurnal Ilmu Kefarmasian Indonesia, 12(2).

Trisnawati, A.R., dan Sari, E.C., 2014. Enkapsulasi Pirazinamid Menggunakan Alginat-Kitosan dengan Variasi Konsentrasi Penambahan Surfaktan Tween 80. UNESA Journal of Chemistry, 3(3).

Uddin, A. B. M. H., Huda, J. H., Mohammed, A., \& Noorsyafawati, A. (2014). High Performance Liquid Chromatographic Determination Of Mefenamic Acid In Human Plasma Using Uv Vis Detector. International Journal of Pharmacy and Pharmaceutical Sciences, 6(11).

Utama, D. A., Esti, H., \& Dewi, M. H. (2013). Pengaruh Kecepatan Pengadukan Terhadap Karakteristik Fisik Mikrosfer Ovalbumin-Alginat dengan Metode Aerosolisasi. PharmaScientia, 2(2). 